\title{
Kinetics and Mechanism of Electron Transfer Reaction of an Adipato Bridged Iron(III)-Salen Complex with Dithionite Ion in Perchloric Acid Medium
}

Pius O. Ukoha, ${ }^{1}$ Simeon Atiga, ${ }^{1}$ Oguejiofo T. Ujam, ${ }^{1,2, *}$ Jonnie N. Asegbeloyin, ${ }^{1}$ Obinna C. Okpareke, ${ }^{1}$ Solomon O. E. Okereke ${ }^{3}$

\footnotetext{
1 Department of Pure and Industrial Chemistry, University of Nigeria, Nsukka, Enugu State, Nigeria

2 Department of Chemistry, University of Victoria, P.O. Box 3065, Victoria, BC V8W3V6, Canada

${ }^{3}$ Department of Pure and Industrial Chemistry, Abia State University, Uturu, Imo State, Nigeria

* Corresponding author's e-mail address: oguejiofo.ujam@unn.edu.ng
}

Abstract: Redox kinetics of the reaction of an adipato bridged iron(III)-salen complex, [(Fe(salen) $)_{2}$ adi] with dithionite ion, $\mathrm{S}_{2} \mathrm{O}_{4}{ }^{2-}$, was investigated in perchloric acid at $I=0.05 \mathrm{~mol} \mathrm{dm}^{-3}\left(\mathrm{NaClO}_{4}\right)$ and $T=29 \pm 1{ }^{\circ} \mathrm{C}$. Spectrophotometric titrations indicated consumption of one mole of $\mathrm{S}_{2} \mathrm{O}_{4}{ }^{2-}$ per mole of [(Fe(salen) $)_{2}$ adi] reduced. Under pseudo-first order conditions of $\left[\mathrm{S}_{2} \mathrm{O}_{4}{ }^{2-}\right]$ above ten-fold excess of concentration of $\left[(\mathrm{Fe}(\mathrm{salen}))_{2}\right.$ adi], observed rates increased with increase in $\left[\mathrm{S}_{2} \mathrm{O}_{4}{ }^{2-}\right]$ and second order rate constants were fairly constant $\left(0.285 \pm 0.01 \mathrm{dm}^{3} \mathrm{~mol}^{-1} \mathrm{~s}^{-1}\right)$ indicating first order dependence of the rate on $\left[(\mathrm{Fe}(\text { salen }))_{2}\right.$ adi]. A plot of $\log k_{\mathrm{obs}}$ versus $\log \left[\mathrm{S}_{2} \mathrm{O}_{4^{2-}}{ }^{2}\right.$ was linear and gave a slope of 1.0 indicating first order dependence of the rate on $\left[\mathrm{S}_{2} \mathrm{O}_{4}{ }^{2-}\right]$. The reaction rate increased with increase in $\left[\mathrm{H}^{+}\right]$within $3 \times 10^{-3} \mathrm{~mol} \mathrm{dm}^{-3} \leq\left[\mathrm{H}^{+}\right] \leq 14 \times 10^{-3} \mathrm{~mol} \mathrm{dm}^{-3}$. The reaction was unaffected by variation of ionic strength and dielectric constant of the medium. Addition of anion and cation did not catalyze the reaction. The reaction has been analyzed on the basis of an inner-sphere mechanism mediated by proton transfer.

Keywords: kinetics, mechanism, dithionite, electron transfer reduction, iron(III)-salen complex.

\section{INTRODUCTION}

$\mathbf{T}$ HE vital importance of iron and its compounds in the functioning of living organisms and metallurgical industries explains the vast interest of researchers in investigating its chemistry. This is evident in many literature reports on the reactivities of iron and it compounds. Particularly, interest in iron biochemistry is enhanced by the participation of iron and its complexes in a wide variety of metabolic and cellular processes. For example, iron-salen derivatives and closely related metal-complexes have been implicated in efficient asymmetric catalysis, in the hydrolytic cleavage of DNA and RNA. ${ }^{[1-3]}$ Dinuclear bridged Fe(III) complexes have also been used as structural models for dinuclear site in proteins involved in oxygen storage by hemerytherin. ${ }^{[4-7]}$. These applications could primarily be attributed to the ease of inter-conversion between ferrous $\{\mathrm{Fe}(\mathrm{II})\}$ and ferric $\{\mathrm{Fe}(\mathrm{III})\}$ states by suitable reductants or oxidants.
We have previously reported the dynamics of electron transfer reactions of the dinuclear iron(III) complex ion, $\left[\mathrm{Fe}_{2} \mathrm{O}\right]^{4+}$, with L-ascorbic acid, ${ }^{[8]} \beta$-mercaptoacetic $\operatorname{acid}^{[9]}$ and $\beta$-mercaptoethanol and mercaptoethylamine. ${ }^{[10]}$ Most of these reactions followed the outer-sphere electron transfer route with intervening ion-pair complexes and free radicals. There are also similar reports of the electron transfer reactions of a 2,2'-bipyridine Fe(III) complex having a $[\mathrm{FeOFe}]^{4+}$ moiety, ${ }^{[11-16]}$ which followed outer-sphere mechanisms. Some of the reactions showed zeroth order dependence on the concentration of the reductant.

Biological systems are structurally complex but can be simplified by the use of synthetic biomimetic molecules in scientific investigations. This unravels the key electronic and structural factors relevant to proteins function ${ }^{[17]}$ and enhances the understanding of the complexities of their reactions. In this report we investigate the reduction of bridged dinuclear Fe(III)-salen complex (a mimic of nonheme binuclear proteins) by dithionite ion, which hitherto 
has not been reported. The effect of varying concentrations of ionic strength, dielectric constant, $\mathrm{H}^{+}, \mathrm{AcO}^{-}$and $\mathrm{Mg}^{2+}$ on the reaction were studied and mechanism for the reaction proposed. The attraction in this study is that it could provide a useful model to further the understanding of the effect of brigding ligands on the redox properties of Fe(III) in a heme protein.

\section{EXPERIMENTAL}

All reagents were analytical grade and used without further purification except otherwise stated. All solutions were prepared with distilled water. UV-visible spectra were recorded on Unico 2012 and Jenway 6405 UV-visible spectrometers. FTIR spectra were obtained on a Shimadzu FTIR spectrometer. Absorbances of solutions were obtained on a B.Bran722-2000 spectronic 20D spectrophotometer. $\left[(\mathrm{Fe}(\text { salen }))_{2}\right.$ adi] was prepared by literature procedures ${ }^{[18,19]}$ involving the reaction of $\left[(\text { Fesalen })_{2} \mathrm{O}\right]^{[20]}$ with adipic acid.

\section{Kinetic Measurements}

The rate data for reduction of the $\mathrm{Fe}(\mathrm{III})$ dimer, $\left[(\mathrm{Fe}(\text { salen }))_{2} \mathrm{adi}\right]$ and consequent oxidation of the dithionite ion were obtained as the decrease in the absorbance of the reacting mixture at $455 \mathrm{~nm}$. At this wavelength only the $\mathrm{Fe}$ (III) dimer absorbed with no interference from the Fe(II) product, the reductant, or the organic product. The reactions were conducted under pseudo-first order conditions with a large excess of the reductant (20-fold in excess of the oxidant). The kinetic curves obtained under this condition were exponential and the rate constant was obtained from the logarithmic plot of $\left(\ln A_{t}-A_{\infty}\right)$ against time $(t)$. Pseudofirst order rate constants were determined from the slope of the plot, based on the following equation:

$$
\ln A_{t}-A_{\infty}=k_{o b s} t+\ln \left(A_{\infty}-A_{0}\right)
$$

where $A_{\infty}=$ final absorbance, $A_{t}=$ absorbance at time $t$, $A_{0}=$ Initial absorbance and $k_{\mathrm{obs}}=$ pseudo-first order rate constant as reported elsewhere. ${ }^{[8,21]}$ Specific rates for replicate runs were reproducible to within $\pm 6 \%$.

The formation of free radical intermediates was detected by monitoring gel formation by acrylamide in partially reacted reaction mixture in excess methanol. ${ }^{[21]}$ The stoichiometry of the reaction was determined by spectrophotometric titrations under the following conditions: concentration of [(Fe(salen) $)_{2}$ adi] kept constant at $1 \times 10^{-4} \mathrm{~mol} \mathrm{dm}^{-3},\left[\mathrm{H}^{+}\right]=$ $5 \times 10^{-3} \mathrm{~mol} \mathrm{dm}^{-3}, I=0.05 \mathrm{~mol} \mathrm{dm}{ }^{-3}\left(\mathrm{NaClO}_{4}\right)$ and $\left[\mathrm{S}_{2} \mathrm{O}_{4}{ }^{2-}\right]$ varied at $1.0 \times 10^{-5} \mathrm{~mol} \mathrm{dm}^{-3} \leq\left[\mathrm{S}_{2} \mathrm{O}_{4}{ }^{2-}\right] \leq 8.0 \times 10^{-4} \mathrm{~mol} \mathrm{dm}^{-3}$ at $T=29 \pm 1^{\circ} \mathrm{C}$. The final absorbances $\left(A_{\infty}\right)$ of separate reaction solutions were plotted against mole ratio, [Red] / [Ox], and the stoichiometry of the reaction derived from the point of inflexion on the curve.

\section{RESULTS AND DISCUSION}

\section{Stoichiometry}

Spectrophotometric titration showed that one mole of $\mathrm{S}_{2} \mathrm{O}_{4}{ }^{2-}$ was consumed per mole of [(Fe(salen $\left.)\right)_{2}$ adi] reduced in accordance with Equation (2).

$$
\begin{aligned}
&\left.2[(\text { Fe(salen }))_{2} \text { adi }\right]+2 \mathrm{~S}_{2} \mathrm{O}_{4}{ }^{2-}+2 \mathrm{H}^{+} \rightarrow \\
& 2\left[(\mathrm{Fe}(\text { salen }))_{2} \text { adiH }\right]^{-}+4 \mathrm{SO}_{2}
\end{aligned}
$$

Similar observations were reported for the reactions of $\mathrm{S}_{2} \mathrm{O}_{4}{ }^{2-}$ with $\left[\mathrm{Fe}_{2}\left(\right.\right.$ bpy)O]Cl ${ }_{4}{ }^{[22]}$ cytochrome c oxidase, ${ }^{[23]}$ cobalticytochrome, ${ }^{[24]}$ nitrogenase ${ }^{[25]}$ and michrosomal cytochrome b5. ${ }^{[26]}$ In most of these reactions dithionite acted as a one or two electron reductant reducing iron(III) to iron(II). Formation and evolution of sulfur(IV) oxide $\left(\mathrm{SO}_{2}\right)$ is common in reactions involving oxidation of dithionite ion. The decolorisation of aqueous $\mathrm{KMnO}_{4}$ by the gaseous product evolved during the reaction confirmed its formation. The presence of $\mathrm{Fe}$ (II) species as one of the products was confirmed by standard literature method ${ }^{[27]}$ by formation of deep blue precipitate on reacting acidified solution of the completed reaction mixture with freshly prepared potassium hexacynoferrate(III). Infrared spectra of ether extract of the product showed bands attributable to $v(\mathrm{M}-\mathrm{N})$ and $v(\mathrm{M}-\mathrm{O})$ in the region $422-543 \mathrm{~cm}^{-1}$. Other observed bands were comparable with those obtained from $\left[(\mathrm{Fe}(\text { salen }))_{2}\right.$ adi $]$, indicating retention of the structure in $\left[(\mathrm{Fe}(\text { salen }))_{2} \text { adi }\right]^{2-}$.

\section{Kinetic Study}

Pseudo-first order decays were linear and fit equation (1) to above $88 \%$ extent of the reaction, indicating first order dependence of rate on concentration of [(Fe(salen $))_{2}$ adi] (the oxidant). Pseudo-first order and second order rate constants are shown in Table 1. Variation of initial concentration of sodium dithionite at $4.0 \times 10^{-3} \mathrm{~mol} \mathrm{dm}^{-3} \leq\left[\mathrm{S}_{2} \mathrm{O}_{4}{ }^{2-}\right] \leq 14.0 \times 10^{-3} \mathrm{~mol} \mathrm{dm}^{-3}$ with $\left[(\mathrm{Fe}(\text { salen }))_{2}\right.$ adi] fixed at $1 \times 10^{-4} \mathrm{~mol} \mathrm{dm}^{-3},\left[\mathrm{H}^{+}\right]$at $5.0 \times 10^{-3}$, ionic strength at $5 \times 10^{-3} \mathrm{~mol} \mathrm{dm}^{-3}\left(\mathrm{NaClO}_{4}\right)$ and $T=29 \pm 1.0^{\circ} \mathrm{C}$ pointed to increase in pseudo-first order rate constant, $k_{\text {obs, }}$ with increase in $\left[\mathrm{S}_{2} \mathrm{O}_{4}{ }^{2-}\right]$. Replicate runs at different concentrations of $\left[\mathrm{S}_{2} \mathrm{O}_{4}{ }^{2-}\right]$ gave $k_{\text {obs }}$ values with less than $5 \%$ standard deviation.

Least mean squares fit $\left(r^{2}=0.967\right)$ of the $\log k_{\text {obs }}$ versus $\log \left[\mathrm{S}_{2} \mathrm{O}_{4}{ }^{2-}\right]$ (Figure 1) was linear with a slope of 1.05 which is in accord with first order dependence of rate of reaction on $\left[\mathrm{S}_{2} \mathrm{O}_{4}{ }^{2-}\right]$. Second order rate constant, 
Table 1. Pseudo-first and second order rate constants for $\mathrm{S}_{2} \mathrm{O}_{4}{ }^{2-}$ $-($ Fe(salen $))_{2}$ adi reaction at $T=29.0 \pm 1{ }^{\circ} \mathrm{C},\left[(\mathrm{Fe}(\text { salen }))_{2}\right.$ adi $]=$ $1 \times 10^{-4} \mathrm{~mol} \mathrm{dm}^{-3}, \lambda_{\max }=455 \mathrm{~nm}, I=0.05 \mathrm{~mol} \mathrm{dm}^{-3}$.

\begin{tabular}{ccc}
\hline $10^{3}\left[\mathrm{~S}_{2} \mathrm{O}_{4}{ }^{2-}\right] / \mathrm{mol} \mathrm{dm}^{-3}$ & $10^{3} k_{\text {obs }} / \mathrm{s}^{-1}$ & $k_{2} / \mathrm{dm}^{3} \mathrm{~mol}^{-1} \mathrm{~s}^{-1}$ \\
\hline 4.0 & 1.20 & 0.30 \\
6.0 & 1.67 & 0.28 \\
8.0 & 2.24 & 0.28 \\
10.0 & 2.85 & 0.29 \\
12.0 & 3.25 & 0.27 \\
14.0 & 3.49 & 0.29 \\
\hline
\end{tabular}

$k_{2}$, were evaluated as the ratio of $k_{\text {obs }}$ to $\left[\mathrm{S}_{2} \mathrm{O}_{4}{ }^{2-}\right]$ and were fairly constant at about $0.285 \pm 0.01 \mathrm{dm}^{3} \mathrm{~mol}^{-1} \mathrm{~s}^{-1}$. These results suggest a rate law in agreement with Equation (3).

$$
-\frac{d}{d t}\left[(\text { Fe }(\text { salen }))_{2} \text { adi }\right]=k_{2}\left[\mathrm{~S}_{2} \mathrm{O}_{4}{ }^{2-}\right]\left[(\text { Fe }(\text { salen }))_{2} \text { adi }\right]
$$

The reaction is second order overall. Some other reactions of $\mathrm{S}_{2} \mathrm{O}_{4}{ }^{2-}$ have been reported to be first order dependent on $\left[\mathrm{S}_{2} \mathrm{O}_{4}{ }^{2-}\right]$. Reaction of cytochrome $c$ oxidase with dithionite ${ }^{[23]}$ was second order overall and first order in $\left[\mathrm{S}_{2} \mathrm{O}_{4}{ }^{2-}\right]$. Reduction of ferricytochrome by dithionite at $I=1.0$ and $T=25^{\circ} \mathrm{C}$ proceeded through two pathways but first order dependence on $\left[\mathrm{S}_{2} \mathrm{O}_{4}{ }^{2-}\right] .{ }^{[28]}$ However, electron transfer from dithionite to microsomal cytochrome b5 was shown to be half order dependent on $\left[\mathrm{S}_{2} \mathrm{O}_{4}{ }^{2-}\right]$ and 1.5 order overall. ${ }^{[26]} \mathrm{Half}$ order dependence on $\left[\mathrm{S}_{2} \mathrm{O}_{4}{ }^{2-}\right]$ was reported for the reaction of $\mathrm{S}_{2} \mathrm{O}_{4}{ }^{2-}$ with cobalticytochrome. ${ }^{[24]}$ First order dependence of the rate on $\left[\mathrm{S}_{2} \mathrm{O}_{4}{ }^{2-}\right]$ is in agreement with its nature as a two-electron reductant. The reduction of the two Fe(III) centers likely took place step-wise, thus the possibility of having a mixedvalence precursor complex of the form [Fe(II)-Fe(III)] $]^{-}$is not

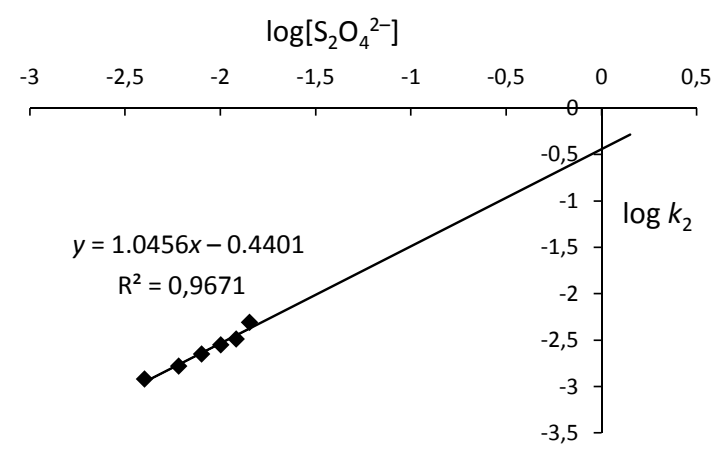

Figure 1. Plot of $\log k_{\mathrm{obs}}$ versus $\log \left[\mathrm{S}_{2} \mathrm{O}_{4}{ }^{2-}\right]$.
Table 2. Effect of $\left[\mathrm{H}^{+}\right]$on the rate of $(\mathrm{Fe}(\text { salen }))_{2}$ adi- $\mathrm{S}_{2} \mathrm{O}_{4}{ }^{2-}$ reaction at $\left[(\mathrm{Fe}(\text { salen }))_{2}\right.$ adi $]=1 \times 10^{-4} \mathrm{~mol} \mathrm{dm}^{-3}, T=29.0 \pm 1^{\circ} \mathrm{C}$, $I=0.05 \mathrm{~mol} \mathrm{dm}^{-3}$.

\begin{tabular}{cccc}
\hline $\begin{array}{c}10^{3}\left[\mathrm{~S}_{2} \mathrm{O}_{4}{ }^{2-}\right] / \\
\mathrm{mol} \mathrm{dm}^{-3}\end{array}$ & $\begin{array}{c}10^{3}\left[\mathrm{H}^{+}\right] / \\
\left.\mathrm{mol} \mathrm{dm}^{-3}\right)\end{array}$ & $\begin{array}{c}10^{3} \mathrm{kobs}_{\mathrm{obs}} / \\
\mathrm{s}^{-1}\end{array}$ & $\begin{array}{c}\mathrm{k}_{2} / \\
\mathrm{dm}^{3} \mathrm{~mol}^{-1} \mathrm{~s}^{-1}\end{array}$ \\
\hline 8.0 & 3.0 & 1.8 & 0.225 \\
8.0 & 5.0 & 2.25 & 0.315 \\
8.0 & 7.0 & 2.94 & 0.368 \\
8.0 & 9.0 & 3.22 & 0.403 \\
8.0 & 11.0 & 3.57 & 0.446 \\
8.0 & 13.0 & 3.95 & 0.494 \\
\hline
\end{tabular}

remote. Iron is a $3 \mathrm{~d}$ metal, and its orbital overlap over the length of the ligand bridge will not be strong enough to cause metal-metal interactions through space over the adipic acid bridge. ${ }^{[29]}$ The iron centers have chemical and electronic properties expected for isolated monomeric iron complex. ${ }^{[18,30]}\left[(\mathrm{Fe}(\text { salen }))_{2}\right.$ adi] has been reported to be magnetically dilute. ${ }^{[18]}$ This infers that the two iron centres are independent to a large extent and have equal chances of being reduced by $\mathrm{S}_{2} \mathrm{O}_{4}{ }^{2-}$.

\section{Acid Dependence}

The effect of $\left[\mathrm{H}^{+}\right]$on the observed rate (Table 2) was investigated with various concentration of $\mathrm{HClO}_{4}$ within the range, $3.0 \times 10^{-3} \mathrm{~mol} \mathrm{dm}^{-3} \leq\left[\mathrm{H}^{+}\right] \leq 13.0 \times 10^{-3} \mathrm{~mol} \mathrm{dm}^{-3}$ at fixed ionic strength, $T=29 \pm 1.0^{\circ} \mathrm{C}$ and kinetic decays observed at $\lambda=455 \mathrm{~nm}$. Within this range of $\left[\mathrm{H}^{+}\right]$, the rate of reaction increased with increase in $\left[\mathrm{H}^{+}\right]$as shown in Table 2. A plot of $k_{2}$ against $\left[\mathrm{H}^{+}\right]$gave a linear plot with an intercept (Figure 2). This result indicates acid-dependence of rate which is in agreement with Equation (4)

$$
k_{\mathrm{H}^{+}}=a+b\left[\mathrm{H}^{+}\right]
$$

where $a=19.20 \times 10^{-2} \mathrm{dm}^{3} \mathrm{~mol}^{-1} \mathrm{~s}^{1}$ and $b=33.83 \mathrm{dm}^{6} \mathrm{~mol}^{-2} \mathrm{~s}^{-1}$.

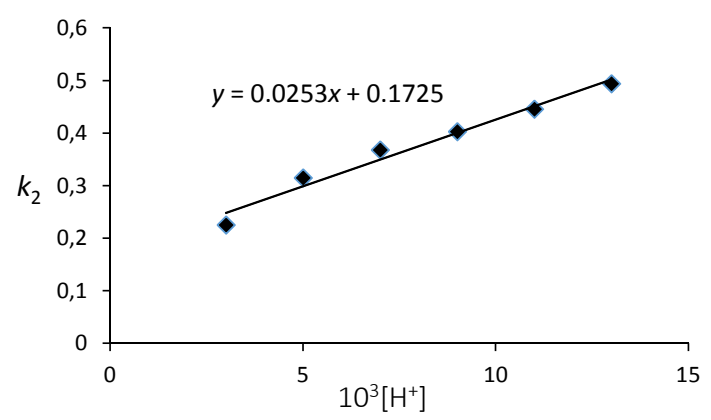

Figure 2. Plot of log $k_{\text {obs }}$ versus $\log \left[\mathrm{S}_{2} \mathrm{O}_{4}{ }^{2-}\right]$. 
Enhancement of the rate of reaction with increasing $\left[\mathrm{H}^{+}\right]$could be interpreted in terms of preprotonation steps leading to formation of protonated precursor species before the electron transfer, $k_{\text {et }}$, step. Dithionite fbetter presented as $\left.\left(\mathrm{O}_{2} \mathrm{SSO}_{2}\right)^{2-}\right\}$ dispropotionates slowly in aqueous solution at $\mathrm{pH} \geq 7$ but rapidly in acid solution assuming the following equilibrium: ${ }^{[31]}$

$$
2 \mathrm{~S}_{2} \mathrm{O}_{4}{ }^{2-}+2 \mathrm{H}_{2} \mathrm{O} \rightleftharpoons \underbrace{2 \mathrm{HSO}_{3}^{-}}_{S(\mathrm{IV})}+\underbrace{\mathrm{SSO}_{3}^{2-}}_{\mathrm{S}(-\mathrm{II}) / \mathrm{S}(\mathrm{VI})}
$$

Such solutions are also known to contain the monomer-dimer equilibrium of the type

$$
\mathrm{S}_{2} \mathrm{O}_{4}{ }^{2-} \rightleftharpoons 2 \mathrm{SO}_{2}^{-}
$$

The acid hydrolysis is second order with respect to $\left[\mathrm{S}_{2} \mathrm{O}_{4}{ }^{2-}\right]$. Protonated species of the type $\mathrm{HSO}_{3}{ }^{-}$participate actively in redox reactions of $\mathrm{S}_{2} \mathrm{O}_{4}{ }^{2-}$. Also the oxidant has proton-acceptor properties and could be protonated to yield charged precursor complexes of the type described in Equation (5).

$$
\left[(\text { Fe }(\text { salen }))_{2} \text { adi }\right]+H^{+} \stackrel{K_{a}}{\rightleftharpoons}\left[(\text { Fe }(\text { salen }))_{2} \text { adiH }\right]^{+}
$$

Protonated species like $\left[(\mathrm{Fe}(\text { salen }))_{2} \mathrm{adiH}^{+}{ }^{+}\right.$(Scheme 1$)$ is likely to be a better oxidant than the neutral complex and it is expected to enhance the reaction rate. Reaction between $\left[(\mathrm{Fe}(\text { salen }))_{2} \mathrm{adiH}\right]^{+}$and $\mathrm{SO}_{2}{ }^{-}$will therefore be more facile than reaction between $\mathrm{S}_{2} \mathrm{O}_{4}{ }^{2-}$ and [( $\mathrm{Fe}($ salen $\left.)\right)_{2}$ adi]. Interaction of either $\mathrm{S}_{2} \mathrm{O}_{3}{ }^{2-}$ or $\mathrm{HSO}_{3}{ }^{-}$with $\left[(\mathrm{Fe}(\text { salen }))_{2} \text { adiH }\right]^{+}$ is likely to result in a precursor complex of inner-sphere character.

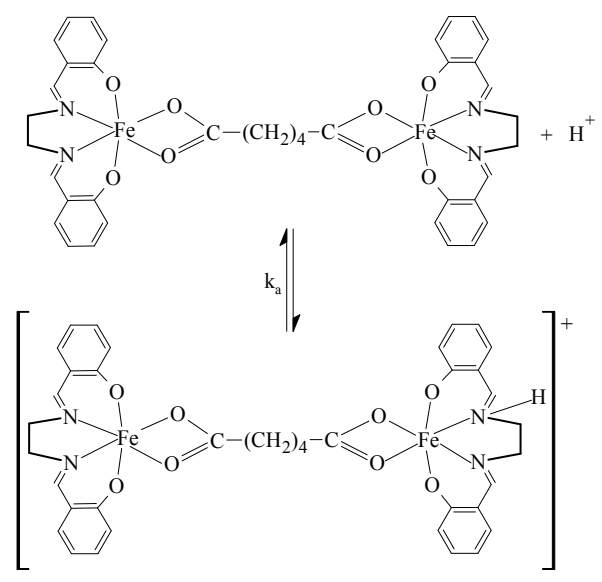

Scheme 1. Protonation of [(Fe(salen $))_{2}$ adi $]$.

\section{Effects of Ionic Strength, Dielectric Con- stant $(D)$ and Added lons}

The effect of the ionic strength was investigated using $\mathrm{NaClO}_{4}$ after certifying that sodium ions produced no catalytic effect (Table 3). At relatively low ionic strength of the medium (0.05-0.15 mol dm${ }^{-3}$ ) with other parameters kept constant, it was observed that $k_{\text {obs }}$ was invariant and remained within the range of $2.90 \times 10^{-3}-3.0 \times 10^{-3} \mathrm{~s}^{-1}$. Based on the Debye-Hückel equation for the reaction of ions in solution [Equation (6)] or a modified Davies equation ${ }^{[32]}$ for relatively high ionic strength [Eq. (7)], primary salt effect is ruled out for the reaction

$$
\begin{aligned}
& \log k_{2}=\log k_{\circ}+Z_{A} Z_{B} \mu^{0.5} \\
& \log k_{2}=\log k_{\circ}+Z_{A} Z_{B}[\sqrt{\mu} /(1+\sqrt{\mu})]
\end{aligned}
$$

where $k_{2}=$ rate constant for the reaction, $k_{0}=$ hypothetical rate constant in a medium of infinite dielectric constant, $Z_{A}, Z_{B}=$ charges on reactants $A$ and $B$ respectively, $\mu=$ ionic strength.

Based on the data in Table 3, a plot of $\log k_{2}$ versus $\sqrt{\mu}$ gave a slope of zero indicating that at the rate determining step, one of the redox partners is neutral. This will be true in a situation where intramolecular electron transfer in the precursor complex, $\left[\mathrm{SO}_{2}-(\mathrm{Fe}(\text { salen }))_{2}\right.$ adi], is the determining step or equally formation of $\left[\mathrm{SO}_{2}-\right.$ (Fe(salen) $)_{2} \operatorname{adiH}^{+}$.

In addition, if there is fast formation of the precursor complex $\left[(\mathrm{Fe}(\text { salen }))_{2} \mathrm{adiH}_{-} \mathrm{SO}_{2}\right]^{-}$, then decomposition of the precursor complex coupled with intramolecular electron transfer in the rate determining step will result in lack of primary salt effect. Rapid scan of the reaction mixture within the first twenty seconds produced evidence of a new species with $\lambda_{\max }$ centered at $520 \mathrm{~nm}$. This suggested the formation of a precursor complex prior to electron transfer.

Table 3. Effect of $\left[\mathrm{H}^{+}\right]$on the rate of $(\mathrm{Fe}(\text { salen }))_{2}$ adi- $\mathrm{S}_{2} \mathrm{O}_{4}{ }^{2-}$ reaction at $\left[(\mathrm{Fe}(\text { salen }))_{2}\right.$ adi $]=1 \times 10^{-4} \mathrm{~mol} \mathrm{dm}^{-3}, T=29.0 \pm 1^{\circ} \mathrm{C}$, $I=0.05 \mathrm{~mol} \mathrm{dm}^{-3}$.

\begin{tabular}{cc}
\hline $1 / \mathrm{mol} \mathrm{dm}^{-3} \mathrm{NaClO}_{4}$ & $\left.10^{3} \mathrm{kobs}_{\mathrm{os}} / \mathrm{s}^{-1}\right)$ \\
\hline 0.05 & 2.90 \\
0.07 & 2.92 \\
0.09 & 2.88 \\
0.11 & 2.95 \\
0.13 & 2.85 \\
0.15 & 2.87 \\
\hline
\end{tabular}


Table 4. Effect of dielectric constant $(D)$ on the rate of (Fe(salen) $)_{2}$ adi- $\mathrm{S}_{2} \mathrm{O}_{4}{ }^{2-}$ reaction.

\begin{tabular}{ccccccc}
\hline$D$ & 74.55 & 68.78 & 63.0 & 57.24 & 51.47 & 45.70 \\
$10^{3} \mathrm{kbss}_{\mathrm{os}} / \mathrm{s}^{-1}$ & 2.80 & 2.92 & 2.90 & 2.68 & 2.92 & 2.98 \\
\hline
\end{tabular}

The effect of dielectric constant $(D)$ of the medium on reaction rate was investigated by varying it between 45.70-74.55 using propan-2-one $/ \mathrm{H}_{2} \mathrm{O}$ mixtures. Results shown in Table 4 show that within this range of $D$, the $k_{\text {obs }}$ was practically unaltered indicating lack of dependence of rate on $D$. This observation suggests non-participation of two charged species at the rate determining step. This is in agreement with the lack of primary salt effect observed (vide supra) and tends to suggest the formation of a precursor complex prior to electron transfer.

The addition of $\mathrm{CH}_{3} \mathrm{COONa}$ and $\mathrm{MgCl}_{2}$ at constant ionic strength had no effect on the reaction. Table 5 shows the variation of $k_{\text {obs }}$ for the reaction in the presence of these ions. Lack of catalysis has been associated with reactions operating by the inner-sphere mechanism. Typical outersphere reaction involving charged species will be accelerated by cations if the redox partners are anions or retarded if oppositely charged redox partners are involved at the rate determining step. ${ }^{[27]}$ For positively charged redox partners addition of anions will reduce repulsion and catalyze the reaction. ${ }^{[33]}$ Lack of catalysis for the $\mathrm{S}_{2} \mathrm{O}_{4}{ }^{2-}-(\mathrm{Fe}(\text { salen }))_{2}$ adi reaction suggests strongly that the reaction is operating by inner-sphere path. Michaelis-Menten-type plot of $1 / k_{\text {obs }}$ versus $1 /\left[\mathrm{S}_{2} \mathrm{O}_{4}{ }^{2-}\right]$ (Figure 3 ) based on the enzymatic reaction rate and modified by Kumar et al. ${ }^{[34]}$ was linear with intercept on the $1 / k_{\text {obs }}$ axis. This is indicative of likely presence of a preassociation step or presence of intermediate with appreciable equilibrium constant. ${ }^{[27]}$ This is the general observation for redox reactions operating by the inner-sphere mechanism.

\section{Temperature Dependence}

The effect of temperature on the rate of reaction was investigated between 302-323 K (Table 6). The results show that the rate of reaction increased with increase in temperature

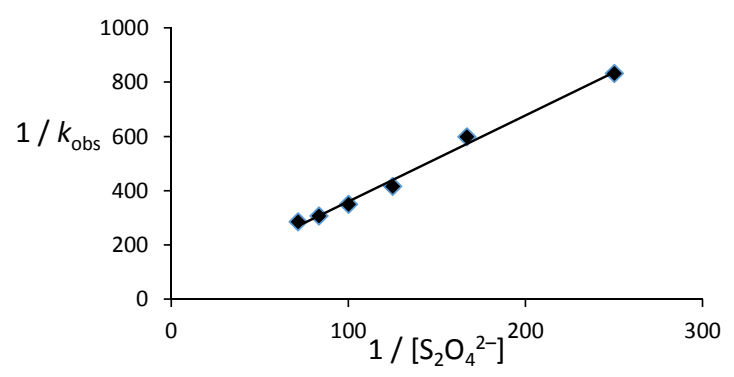

Figure 3. Plot of $1 /\left[\mathrm{S}_{2} \mathrm{O}_{4}{ }^{2-}\right]$ versus $1 / k_{\text {obs }}$.
Table 5. Effect of added ions on the rate of $(\mathrm{Fe}(\text { salen }))_{2}$ adi- $\mathrm{S}_{2} \mathrm{O}_{4}{ }^{2-}$ reaction at $\left[\mathrm{S}_{2} \mathrm{O}_{4}{ }^{2-}\right]=12 \times 10^{-3} \mathrm{~mol} \mathrm{dm}^{-3},\left[(\mathrm{Fe}(\text { salen }))_{2}\right.$ adi $]=$ $1 \times 10^{-4}, T=29.0 \pm 1^{\circ} \mathrm{C}$.

\begin{tabular}{cccccc}
\hline $10^{3}\left[\mathrm{CH}_{3} \mathrm{COO}^{-}\right] / \mathrm{mol} \mathrm{dm}^{-3}$ & 6.0 & 8.0 & 10.0 & 12.0 & 14.0 \\
$10^{3} \mathrm{kobs} / \mathrm{s}^{-1}$ & 3.20 & 3.25 & 3.20 & 3.23 & 3.28 \\
$10^{3}\left[\mathrm{Mg}^{2+}\right] / \mathrm{mol} \mathrm{dm}^{-3}$ & 6.0 & 8.0 & 10.0 & 12.0 & 14.0 \\
$10^{3} \mathrm{kobs} / \mathrm{s}^{-1}$ & 3.25 & 3.22 & 3.26 & 3.28 & 3.25 \\
\hline
\end{tabular}

within the stated range. Least-squares fit of $\log \left(k_{\mathrm{obs}} / T\right)$ versus $1 / T$ based on the Eyring-Polanyi Equation (8) was linear with intercept at -4.8

$$
k_{r}=\left(\frac{k T}{h}\right) \exp \left(\frac{\Delta S^{\#}}{R}\right) \exp \left(-\frac{\Delta H^{\#}}{R T}\right)
$$

where $k_{r}$ - rate constant, $k$ - Boltzmann's constant, $h-$ Planck's constant, $\Delta S^{\#}$ - entropy of activation, $\Delta H^{\#}$ - enthalpy of activation, $T$ - absolute Temperature, $R$ - gas constant.

$\Delta H^{\#}$ and $\Delta S^{\#}$ were evaluated from the slope and intercept determined to be $10.94 \mathrm{~kJ} \mathrm{~mol}^{-1}$ and $-291.20 \mathrm{~J} \mathrm{~mol}^{-1} \mathrm{~K}^{-1}$ respectively. Similar results have been reported for other inner-sphere reactions. ${ }^{[35-37]}$ The redox reaction of [ $\mathrm{Mn}($ salen $) \mathrm{H}_{2} \mathrm{O}$ ] with ascorbic acid proceeded by the inner-sphere path, $\Delta H^{\#}\left(89.2 \mathrm{~kJ} \mathrm{~mol}^{-1}\right)$ and $\Delta S^{\#}(54.6)$ were reported. ${ }^{[35]}$ These results were rationalized in terms of enthalpy controlled reaction which is a common feature of slow reactions. The inner-sphere oxidation of $\mathrm{Cr}$ (III) guanosine complex by $1 \mathrm{IO}_{4}^{-}$has value $\Delta S^{\#}\left(-130 \mathrm{~J} \mathrm{~K}^{-1} \mathrm{~mol}^{-1}\right)$ and $\Delta H^{\#}\left(42.2 \mathrm{~kJ} \mathrm{~mol}^{-1}\right){ }^{\left[{ }^{[3]}\right]}$ The negative $\Delta S^{\#}$ was interpreted in terms of mutual ordering of the solvated water molecules and the $\Delta H^{\#}$ value was rationalized on the basis of an endothermic reaction. Dixon et al. ${ }^{[38]}$ reported $\Delta S^{\#}(93 \pm$ $\left.45 \mathrm{~J} \mathrm{~K}^{-1} \mathrm{~mol}^{-1}\right)$ and $\Delta H^{\#}\left(105 \mathrm{~kJ} \mathrm{~mol}^{-1}\right)$ for the inner-sphere electron transfer reaction between L-ascorbic acid with $\left[\left(\mathrm{NH}_{3}\right)_{5} \mathrm{CoOH}\right]^{2+}$. These results also supported a reaction requiring high energy to attain transition state but with

Table 6. Temperature-dependent rate constants for $(\text { Fe(salen) })_{2}$ adi- $\mathrm{S}_{2} \mathrm{O}_{4}{ }^{2-}$ reaction at $\left[\mathrm{S}_{2} \mathrm{O}_{4}{ }^{2-}\right]=12 \times 10^{-3} \mathrm{~mol} \mathrm{dm}^{-3}$, $[(\text { Fe(salen }))_{2}$ adi $]=1 \times 10^{-4}, T=29.0 \pm 1^{\circ} \mathrm{C},\left[\mathrm{H}^{+}\right]=5 \times 10^{3} \mathrm{~mol} \mathrm{dm}^{-3}$, $I=0.05 \mathrm{~mol} \mathrm{dm}^{-3}\left(\mathrm{NaClO}_{4}\right)$ and $\lambda_{\max }=455 \mathrm{~nm}$.

\begin{tabular}{cccc}
\hline$T / \mathrm{K}$ & $10^{3} \mathrm{kobs}_{\mathrm{s}} / \mathrm{s}^{-1}$ & $\log \left(\mathrm{k}_{\mathrm{obs}} / T\right)$ & $10^{3}(1 / T)$ \\
\hline 302 & 2.86 & -5.02 & 3.31 \\
308 & 3.10 & -5.00 & 3.25 \\
313 & 3.53 & -4.95 & 3.19 \\
318 & 3.82 & -4.92 & 3.14 \\
323 & 4.10 & -4.90 & 3.10 \\
\hline
\end{tabular}


poorly organized transition state or where bond breaking was dominant. Most probably, the negative $\Delta S^{\#}$ of the $\mathrm{S}_{2} \mathrm{O}_{4}{ }^{2-}-$ (Fe(salen) $)_{2}$ adi reaction is due to a rate determining step where bond formation dominated leading to mutual ordering of solvated molecules. Electron transfer and breakdown of the precursor complex $\left[\mathrm{SO}_{2}-(\mathrm{Fe}(\text { salen }))_{2}\right.$ adi] dominated in this reaction.

\section{Mechanism of Reaction}

Considering the stoichiometry, acid-dependence, effect of ionic strength, effect of dielectric constant, catalysis, formation of intermediates and Michaelis-Menten-type plot, the following scheme has been proposed for the reaction:

$\left[(\text { Fe }(\text { salen }))_{2}\right.$ adi $]+H^{+} \stackrel{\kappa_{\mathrm{p}}}{\rightleftharpoons}($ Fe(salen $\left.)\right)_{2} \operatorname{adiH}^{+}$

$$
\mathrm{S}_{2} \mathrm{O}_{4}{ }^{2-} \stackrel{K_{\mathrm{d}}}{\rightleftharpoons} 2 \mathrm{SO}_{2}^{-}
$$

(Fe(salen) $)_{2} \operatorname{adiH}^{+}+\mathrm{SO}_{2}{ }^{-} \stackrel{K_{1}, \text { fast }}{\rightleftharpoons}$

$$
\left[(\mathrm{Fe}(\text { salen }))_{2} \mathrm{adiH}-\mathrm{SO}_{2}\right]
$$

$$
\begin{array}{r}
\left.[(\text { Fe(salen }))_{2} \text { adiH }-\mathrm{SO}_{2}\right] \stackrel{k_{2} \text {, slow }}{\rightleftharpoons} \\
(\mathrm{Fe}(\text { salen }))_{2} \text { adiH }+\mathrm{SO}_{2} \\
(\mathrm{Fe}(\text { salen }))_{2} \text { adiH }+\mathrm{SO}_{2}{ }^{-} \stackrel{k_{3}, \text { slow }}{\rightleftharpoons}
\end{array}
$$

$$
(\mathrm{Fe}(\text { salen }))_{2} \mathrm{adiH}^{-}+\mathrm{SO}_{2}
$$

(Fe(salen) $)_{2}$ adi $+\mathrm{S}_{2} \mathrm{O}_{4}{ }^{2-} \stackrel{k_{4} \text {, fast }}{\rightleftharpoons}$

$$
\left[(\mathrm{Fe}(\text { salen }))_{2} \mathrm{adiH}-\mathrm{SO}_{2}\right]^{-}+\mathrm{SO}_{2}^{-}
$$

$$
\begin{aligned}
{\left[(\mathrm{Fe}(\text { salen }))_{2} \text { adiH }-\mathrm{SO}_{2}\right]^{-} \stackrel{k_{5}, \text { slow }}{\rightleftharpoons} } \\
(\mathrm{Fe}(\text { salen }))_{2} \mathrm{adi}^{-}+\mathrm{SO}_{2}
\end{aligned}
$$

$$
\begin{aligned}
(\mathrm{Fe}(\text { salen }))_{2} \mathrm{adi}^{-}+\mathrm{SO}_{2}{ }^{-} \stackrel{\mathrm{k}_{6}, \text { fast }}{\rightleftharpoons} \underset{(\mathrm{Fe}(\text { salen }))_{2} \mathrm{adi}^{2-}+\mathrm{SO}_{2}}{\rightleftharpoons}
\end{aligned}
$$

$$
\left.(\text { Fe(salen }))_{2} \operatorname{adi}^{2-}+\mathrm{H}^{+} \stackrel{k_{7} \text {, fast }}{\rightleftharpoons}(\text { Fe(salen })\right)_{2} \text { adiH }^{-}
$$

$$
\begin{aligned}
& \text { Rate }=-\frac{d\left[(\mathrm{Fe}(\text { salen }))_{2} \mathrm{adi}\right]}{d t}= \\
& k_{2}\left[(\mathrm{Fe}(\text { salen }))_{2} \text { adiH }-\mathrm{SO}_{2}\right]+k_{5}\left[(\mathrm{Fe}(\text { salen }))_{2} \text { adi }-\mathrm{SO}_{2}\right]
\end{aligned}
$$

following steady state approximation: $[(\text { Fe(salen }))_{2}$ adiH $\left.-\mathrm{SO}_{2}\right]=k_{1}\left[(\mathrm{Fe}(\text { salen }))_{2} \mathrm{adiH}^{+}\right] \times$

$$
\left.\left[\mathrm{SO}_{2}^{-}\right]-k_{2}[(\text { Fe(salen }))_{2} \text { adiH }-\mathrm{SO}_{2}\right]=0
$$

$\left[(\mathrm{Fe}(\text { salen }))_{2}\right.$ adi $\left.-\mathrm{SO}_{2}\right]=$

$$
\frac{k_{1}}{k_{2}}\left[(\text { Fe }(\text { salen }))_{2} \text { adiH }^{+}\right]\left[\mathrm{SO}_{2}^{-}\right]
$$

Also:

$\left.[(\text { Fe(salen }))_{2} \operatorname{adiH}^{+}\right]=K_{\mathrm{p}}[(\text { Fe(salen }))_{2}$ adi $]\left[\mathrm{H}^{+}\right]$

and:

$$
\left[\mathrm{SO}_{2}^{2-}\right]=K_{\mathrm{d}}\left[\mathrm{S}_{2} \mathrm{O}_{4}^{2-}\right]
$$

Substituting [Eq. (20)] and [Eq. (21)] into [Eq. (19)] gives:

$$
\begin{aligned}
& \left.[(\text { Fe(salen }))_{2} \text { adiH }-\mathrm{SO}_{2}\right]= \\
& \left.\quad \frac{K_{\mathrm{d}} k_{1} K_{\mathrm{p}}}{k_{2}}[(\text { Fe(salen }))_{2} \text { adi }\right]\left[\mathrm{H}^{+}\right]\left[\mathrm{S}_{2} \mathrm{O}_{4}{ }^{2-}\right]
\end{aligned}
$$

By recourse to steady state approximation:

$$
\begin{aligned}
& {\left[(\mathrm{Fe}(\text { salen }))_{2} \text { adiH }-\mathrm{SO}_{2}{ }^{-}\right]=k_{4}\left[(\mathrm{Fe}(\text { salen }))_{2} \text { adi }\right] \times} \\
& {\left[\mathrm{S}_{2} \mathrm{O}_{4}{ }^{2-}\right]-k_{5}\left[(\mathrm{Fe}(\text { salen }))_{2} \text { adi }-\mathrm{SO}_{2}{ }^{-}\right]=0} \\
& {\left[(\mathrm{Fe}(\text { salen }))_{2} \text { adi }-\mathrm{SO}_{2}{ }^{-}\right]=} \\
& \frac{k_{4}}{k_{5}}\left[(\mathrm{Fe}(\text { salen }))_{2} \text { adi }\right]\left[\mathrm{S}_{2} \mathrm{O}_{4}{ }^{2-}\right]
\end{aligned}
$$

Substituting [Eq. (22)] and [Eq. (23)] into [Eq. (18)] gives:

$$
\begin{aligned}
- & \left.\frac{\left.d[(\text { Fe(salen }))_{2} \text { adi }\right]}{d t}=K_{\mathrm{d}} K_{\mathrm{p}} k_{1}[(\text { Fe(salen }))_{2} \text { adi }\right]\left[\mathrm{H}^{+}\right] \times \\
& {\left.\left[\mathrm{S}_{2} \mathrm{O}_{4}{ }^{2-}\right]+k_{4}[(\text { Fe(salen }))_{2} \text { adi }\right]\left[\mathrm{S}_{2} \mathrm{O}_{4}{ }^{2-}\right]=} \\
& {\left[(\text { Fe(salen) })_{2} \text { adi }\right]\left[\mathrm{H}^{+}\right]\left[\mathrm{S}_{2} \mathrm{O}_{4}{ }^{2-}\right]\left\{K_{\mathrm{d}} K_{\mathrm{p}} k_{1}\left[\mathrm{H}^{+}\right]+k_{4}\right\} }
\end{aligned}
$$


Equation (24) is similar to Equation (4):

$$
a=K_{\mathrm{d}} K_{\mathrm{p}} k_{1} \text { and } b=k_{4}
$$

The pathway followed for reduction of [(Fe(salen) $)_{2}$ adi] by $\left[\mathrm{S}_{2} \mathrm{O}_{4}{ }^{2-}\right]$ was resolved by considering the following points: (1) Absence of catalysis by $\mathrm{AcO}^{-}$and $\mathrm{Mg}^{2+}$ indicates operation of an inner-sphere mechanism and suggests $\mathrm{SO}_{2}{ }^{-}$ as the main reductant species. Formation of a precursor complex of the form $\left[(\mathrm{Fe}(\text { salen }))_{2} \mathrm{adiHSO}_{2}\right]^{-}$which undergoes intramolecular electron transfer rules out any available site for attack by anions and hence lack of catalysis. (2) Plot of $1 / k_{\text {obs }}$ against $1 /\left[\mathrm{S}_{2} \mathrm{O}_{4}{ }^{2-}\right]$ was linear with positive intercept suggesting formation of a precursor complex of large enough equilibrium constant. (3) Rapid scanning of the reaction mixture within the first 20 seconds showed a new $\lambda_{\max }$ centered around $520 \mathrm{~nm}$. Similar complexes of inner-sphere character has been reported for oxoanion reactions. ${ }^{[36]}$ (4) Lack of dependence of the rate of reaction on ionic strength suggests interaction of the redox partners with a zero product of charge indicating likely intramolecular electron transfer in a preassociation complex. These data strongly supports the view that the reaction followed the inner-sphere electron transfer mechanism in accordance with the proposed reaction scheme.

\section{CONCLUSIONS}

This study was undertaken to investigate the kinetics of the reduction of $\left[(\mathrm{Fe}(\text { salen }))_{2}\right.$ adi] by dithionite, and a reaction mechanism has been proposed. The overall rate law for the reaction is determined as

$$
\begin{aligned}
& \text { Rate }=-\frac{d}{d t}\left[(\mathrm{Fe}(\text { salen }))_{2} \text { adi }\right]= \\
& K_{\mathrm{d}}\left[(\mathrm{Fe}(\text { salen }))_{2} \text { adiH }\right]\left[\mathrm{S}_{2} \mathrm{O}_{4}^{2-}\right]\left(\frac{k_{2} K_{\mathrm{a}} k_{1}}{k_{-1}}\left[\mathrm{H}^{+}\right]+\frac{k_{4} k_{3}}{k_{-3}}\right)
\end{aligned}
$$

The increase in the rate constants with an increasing $\left[\mathrm{H}^{+}\right]$is in accord with the proposed mechanism of the reaction.

Acknowledgements: Simeon Atiga thanks the Department of Pure and Industrial Chemistry, University of Nigeria, Nsukka for some financial assistance. We thank John I. Ugwu and Amara Chukwuneke for technical support.

\section{REFERENCES}

[1] M. Komiyama, J. Sumaoka, Curr. Opin. Chem. Biol. 1998, 2, 751.
[2] K. I. Ansari, J. D. Grant, G. A. Woldemariam, S. Kasiri, S. S. Mandal, Org. Biomol. Chem. 2009, 7, 926.

[3] G. A. Woldemariam, S. S. Mandal, J. Inorg. Biochem. 2008, 102, 740.

[4] S. Sheriff, W. A.Hendrickson, J. L. Smith, J. Mol. Biol. 1987, 197, 273.

[5] R. E. Stenkamp, L. C. Sieker, L. H. Jesen, J. Am. Chem. Soc. 1984, 106, 618.

[6] A. C. Rosenzweig, C. A. Frederick, S. J. Lippard, P. Nordlund, Nature 1993, 366, 537.

[7] A. C. Rosenzweig, P. Nordlund, P. M.Takahara, C. A. Frederick, S. J. Lippard, Chem. and Bio. 1995, 2, 409.

[8] P. O. Ukoha, J. F. Iyun, J. Chem. Soc. Nig. 2002, 27, 119.

[9] P. O. Ukoha, J. F. Iyun, Chem. Class J. 2005, 2, 51.

[10] P. O. Ukoha, J. F. Iyun, J. Chem. Soc. Nig. 2001, 26, 163.

[11] S. O. Idris, J. F. Iyun, E. B. Agabji, Trans. Met. Chem. 2009, 34, 205.

[12] S. O. Idris, J. F. Iyun, E. B. Agabji, Inter. J. Chem. Appl. 2011, 3, 159.

[13] S. O. Idris, J. F. Iyun, E. B. Agabji, Afr. J. Nat. Sci. 2007, $10,35$.

[14] S. O. Idris, J. F. Iyun, E. B. Agabji, Ife J. Sc. 2008, 10, 103.

[15] S. O. Idris, J. F. Iyun, E. B. Agabji, Chem. Class J. 2004, $1,27$.

[16] S. O.Idris, J. F. Iyun, E. B. Agabji, Chem. Class J. 2005, 2, 85 .

[17] R. Bikas, H. Hosseini-Monfared, G. Zoppellaro, R. Herchel, J. Tucek, A.M. Owczarzak, M. Kubicki, R. Zboril, Dalt. Trans. 2013, 42, 2803.

[18] Z. Smékal, F. Brezina, Z. Sindelar, R. Klicka, M. Nadvornik, Trans. Met. Chem. 1996, 21, 49.

[19] S. Atiga, P. O. Ukoha, O. T. Ujam, C. O. Okpareke, Trans. Met. Chem. 2014, 39, 189.

[20] M. Tanaka, M. Kitaoka, H. Okawa, S. Kida, Bull. Chem. Soc. Japan 1976, 49, 2469.

[21] P. O.Ukoha, C. Alioke, J. N. Asegbeloyin , O. T. Ujam, J. Chem. Soc. Nig. 2010, 35, 163.

[22] S. O. Idris, J. F. Iyun, E. B. Agabji, Chem. Class J. 2005, 2, 85 .

[23] G. D. Jones, M. G. Jones, M. T. Wilson, M. Brunori, A. Colosimo, P. Sarti, Biochem. 1983, 209, 175.

[24] J. C. W. Chien, L. C. Dickson, J. Biol. Chem. 1978, 253, 6965.

[25] G. A. Ashby, R. N. Thorneley, Biochem. 1978, 246, 455.

[26] D. M. Davis, J. M. Lawther, Biochem. 1978, 258, 375.

[27] C. U. Alioke, P. O. Ukoha, N. N. Ukwueze, O. T. Ujam, J.N. Asegbeloyin, Chem. Mat. Res. 2012, 2, 48.

[28] C. Creutz, N. Sutin, Proceedings of National Academy Science, USA, 1973, 70, 1701. 
[29] M. B. Robin, P. Day, Adv. Inorg. Chem. Radiochem. 1976, 10, 247.

[30] T. R. Weaver, T. J. Meyer, S. A. Adeyemi, G. M. Brown, R. P. Eckberg, E. W. Hatfield, E. C. Johnson, R. W. Murray, D. Untereker, J. Am. Chem. Soc. 1975, 97, 3039.

[31] N. M. Greenwood, A. Earnshaw, Chemistry of Elements, Butterworth-Heinemann, Oxford, 2003.

[32] C. W. Devies, Ion-Association., Butterworth and Co., Ltd., London, 1962.

[33] T. J. Przystas, N. Sutin, J. Am. Chem. Soc. 1973, 95, 5545.
[34] C. S. Kumar, U. Chandraiah, M. A. A. Siddigui, S. Kordlikars, Ind. J. Chem. A 1991, 30, 714.

[35] I. A. Salem, A. H. Gemeay, Trans. Met. Chem. 1996, 21, 130.

[36] H. A. Ewais, S. A. Ahmed, A. A. Abdel-Khalek, J. Chin. Chem. Soc. 2004, 51, 713.

[37] D. A. Dixon, N. P. Sadler, T. P. Dasgupta, Trans. Met. Chem. 1995, 20, 295.

[38] U. Chandrawat, A. Prakash, R. N. Mehrotra, Can. J. Chem. 1995, 73, 1531. 